\title{
Immunohistochemical Aspects of Cell Death in Diabetic Nephropathy
}

\author{
ELENA BĂLĂŞESCU ${ }^{1}$, MIRELA CIOPLEA², ALICE BRÎNZEA ${ }^{3}$, ROXANA NEDELCU $^{3}$, \\ SABINA ZURAC ${ }^{2}$, DANIELA ADRIANA ION ${ }^{3}$ \\ ${ }^{1}$ CMDT Roma, Bucharest, Romania \\ ${ }^{2}$ Department of Pathology, "Colentina" Clinical Hospital, "Carol Davila" University of Medicine and Pharmacy, Bucharest, Romania \\ ${ }^{3}$ Department of Pathophysiology II, "Carol Davila" University of Medicine and Pharmacy, Bucharest, Romania
}

\begin{abstract}
Introduction. Diabetes Mellitus causes ultrastructural changes triggered by partially clarified cellular mechanisms. Since cell death is an important mechanism in the appearance and progression of diabetic nephropathy, we studied alteration of several markers of apoptotic pathways signaling in renal tissue of diabetic or prediabetic patients.

Methods. We analyzed 48 human kidney tissue samples divided into two study groups: the research group (43 renal tissue samples from diabetic or prediabetic patients), and the control group (5 renal tissue samples from patients without diabetes). Immunohistochemistry revealed expression of Bcl-2, APAF-1, CD-95 and Caspase-9 in the renal cortical structures. Statistical analysis was also performed (significance level $\mathrm{P}<0.05$ ).

Results. We found a variable expression of the antiapoptotic Bcl-2 with a decrease of Bcl-2 expression in diabetes. The control samples render evident intensely positive immunostaining for CD-95. In diabetes and diabetic nephropathy, there was positive immunostaining for APAF-1 at tubular cell level. Nuclear and cytoplasmic positivity for Caspase-9 was more frequently recorded as kidney damage progresses. APAF-1 and Caspase-9 positivity are arguments for an intrinsic apoptotic mechanism of cell death in diabetic nephropathy.

Conclusion. The mechanisms of apoptotic cell death identified in diabetic kidney samples prove that Bcl-2, CD-95, APAF-1 and Caspase-9 represent reliable markers of cell death in human renal tissue. Our results support the hypothesis that apoptosis is a pathogenic and initiator mechanism of renal remodeling in diabetic kidney disease.
\end{abstract}

Key words: diabetes, cell death, apoptosis, immunohistochemistry, caspases.

\section{INTRODUCTION}

International Federation of Kidney Foundations and International Society of Nephrology established that diabetes is the cause of almost one-third of all cases of kidney disease and one of the most common causes of End Stage Renal Disease in developed countries [1].

Recent data of the World Health Organization shows that Diabetes Mellitus affected $9 \%$ of the global adult population in 2014 [2]. In the past three decades, the number of people with diabetes has doubled, and 1.5 million deaths due to diabetes are annually [3] registered; moreover, diabetes is expected to become the seventh leading cause of death worldwide in 2030 [2]. As Diabetes ranges among the leading causes of kidney failure, approximately a quarter of the diabetic patients develop renal impairment with a mortality rate of about 40 times [4] higher than those without a proteinuria.
Since Diabetes causes ultrastructural changes triggered by partially clarified cellular mechanisms, our aim was to study the balance between cell death and cell proliferation in the renal cortex; thus we intend to identify how apoptotic cell death influences renal structures in diabetic human kidney samples.

\section{MATERIAL AND METHODS}

The study conducted on human autopsy samples comprised a research group of 43 renal tissue samples from patients with clinically or pathologically confirmed diabetes or prediabetes and a control group of 5 renal tissue samples of patients without diabetes. We conceived a first study group (Type 2 Diabetes) with 29 renal samples [12 cases without renal impairment $(7 \mathrm{~F}: 5 \mathrm{M}$, aged 45-87 years), and 17 cases with renal impairment (9F:8M, 59-94 years)]; the second study group (Prediabetes) had 14 renal tissue samples $(6 \mathrm{~F}: 8 \mathrm{M}$, 
45-95 years), whereas the Control group (Non diabetic) contained 5 renal tissue samples (1F:4M), 65-81 years); all the patients from the control group had cardiovascular problems (3 patients with arterial hypertension, 2 patients with ischemic cardiac disease) without any renal impairment.

We strictly followed the initially proposed enrollment requirements (renal tissue samples from patients with Type 2 Diabetes aged between 40 and 95 years with pathologically confirmed diabetic renal injury). We excluded cases with induced immunosuppression or pathological states, infectious conditions or presence of renal pathologies unrelated with diabetic kidney disease (acute kidney injury, tumors, nephrolithiasis, polycystic kidney disease, etc.).

According to the American Diabetes Association, fasting blood glucose of $100-125 \mathrm{mg} / \mathrm{dL}$, A1c of $5.7-6.4 \%$ or casual plasma glucose test lower than $199 \mathrm{mg} / \mathrm{dL}$ [5] were considered prediabetes cases.

Histopathological tissue processing was performed according to current protocols. After paraffin impregnation, tissue samples were included in blocks and cut with a rotary microtome in sections of only 3-micron thick; slides for simple routine staining (hematoxylin and eosin - HE) and immunohistochemistry staining (IHC) were displayed. HE and IHC staining techniques were conducted under current legislation (Ord. 1.217/16.09.2010). IHC tests used primary antibodies APAF-1 (rabbit, 10/ 100 , heat induced epitope retrieval $\mathrm{pH} 8.00$ buffer EDTA, Leica), CD-95 (clone GM30, mouse, 4/100, heat induced epitope retrieval $\mathrm{pH} 6.00$ buffer citrate, Neo Markers), Bcl-2 (clone bcl-2/100/D5, mouse, 1.5/100, heat induced epitope retrieval $\mathrm{pH} 6.00$ buffer citrate, Leica), Caspase-9 (mouse, 0.25/250, heat induced epitope retrieval $\mathrm{pH} 8.00$ buffer EDTA, Novus), Novolink kit (Leica) and liquid DAB as chromogen (Leica).

Our study evaluated the immunohistochemical expression of antiapoptotic protein Bcl-2, APAF-1 (apoptosis-activating factor 1)/(apoptotic protease activating factor), CD-95 (Fas receptor/ antigen apoptosis 1) and Caspase-9 in the renal cortical structures. All the stains were evaluated as positive (obvious positivity, no matter of how many cells were positive) or negative (absence of expression or weak focally positivity). We used this simplified approach due to the high reproducibility of the system. The pathologist (MC) evaluated all the slides without knowing which specific case she evaluates. We used the statistical software Graph Pad InStat, performing the Fisher Exact Test. The null hypothesis was rejected for a significance level lower than 0.05 .

Further to the approval of the Ethics Committee, we conducted this study with data from medical records belonging to patients deceased in Colentina University Hospital from 2007 until 2014.

\section{RESULTS}

IHC staining revealed a variable expression of the antiapoptotic Bcl-2 protein (positive - in capsular parietal and inflammatory cells, and negative - focal weak positivity in the proximal and distal tubules). We noticed fewer cases with $\mathrm{Bcl}-2$ expression in diabetes than in prediabetes or controls. Bcl-2 was more frequently expressed in samples from control group $(60 \%$ of positive samples) compared with samples from the whole diabetic group (with and without renal impairment) in which only $17.25 \%$ of samples were positive for Bcl-2, although $\mathrm{p}$ value was not statistically significant $(p=0.07)$. Albeit Bcl-2 was better expressed in control samples (Figure 1a) compared with the diabetic group (Figure 1b) there were some tissue samples from diabetic nephropathy group which revealed high Bcl-2 expression (Figure 1c).

In order to identify signals involved in extrinsic pathway of cell death, we studied expression of Fas receptor (CD-95). Control samples (Figure 2a) showed intensely positive immunostaining for CD95 in the glomeruli, endothelial cells and proximal tubular cells. Some cases of prediabetes were positive (Figure $2 \mathrm{~b}$ ), CD-95 positivity being also recorded in diabetic renal tissue with or without renal impairment (Figures 2c,d). All the samples (100\% of samples) in control group expressed CD-95 compared with samples from patients with diabetes and renal impairment ( $41.17 \%$ of samples), with a statistically significant result $(p=0.039)$. Also, the results are statistically significant $(p=0.009)$ on CD-95 positivity in control samples $(100 \%$ of samples positivity) compared with samples from diabetic patients without renal impairment $(25 \%$ of samples) (Table 2).

In order to investigate cellular signaling on intrinsic pathway of apoptosis, we studied the 
expression of APAF-1 and Caspase-9. Consistent with APAF-1 activation as one of the first steps in the intrinsic apoptosis signaling pathway, we identified negativity of all cases (weak or no positivity) for APAF-1 in controls, with some cases had APAF-1 positivity in patients with diabetes and renal impairment. In these cases (diabetes and diabetic nephropathy), we observed positive APAF-1 immunostaining notably in tubular cells (Figures $3 a, b)$. APAF-1 positivity has a statistically significant association with diabetes and renal impairment comparing with diabetes without renal impairment group $(\mathrm{p}=0.02)$ (Table 3$)$.

Caspase-9 labeling highlighted tubular and glomerular cells (in both nucleus and cytoplasm) with an increased tendency towards Caspase-9 expression as kidney damage progresses (Figures 4a,b). Caspase-9 expression was present in almost all cases: control group $-100 \%$ of samples, patients with diabetes and renal impairment $-100 \%$ of samples and patients with diabetes without renal impairment $-91.66 \%$ of samples. The lowest proportion of positivity was recorded among patients with prediabetes ( $50 \%$ of cases). Those results that indicate Caspase- 9 positivity better represented in samples from patients with diabetes and renal impairment compared with samples from prediabetic group are highly statistically significant $(p=0.001)$ (Table 4).
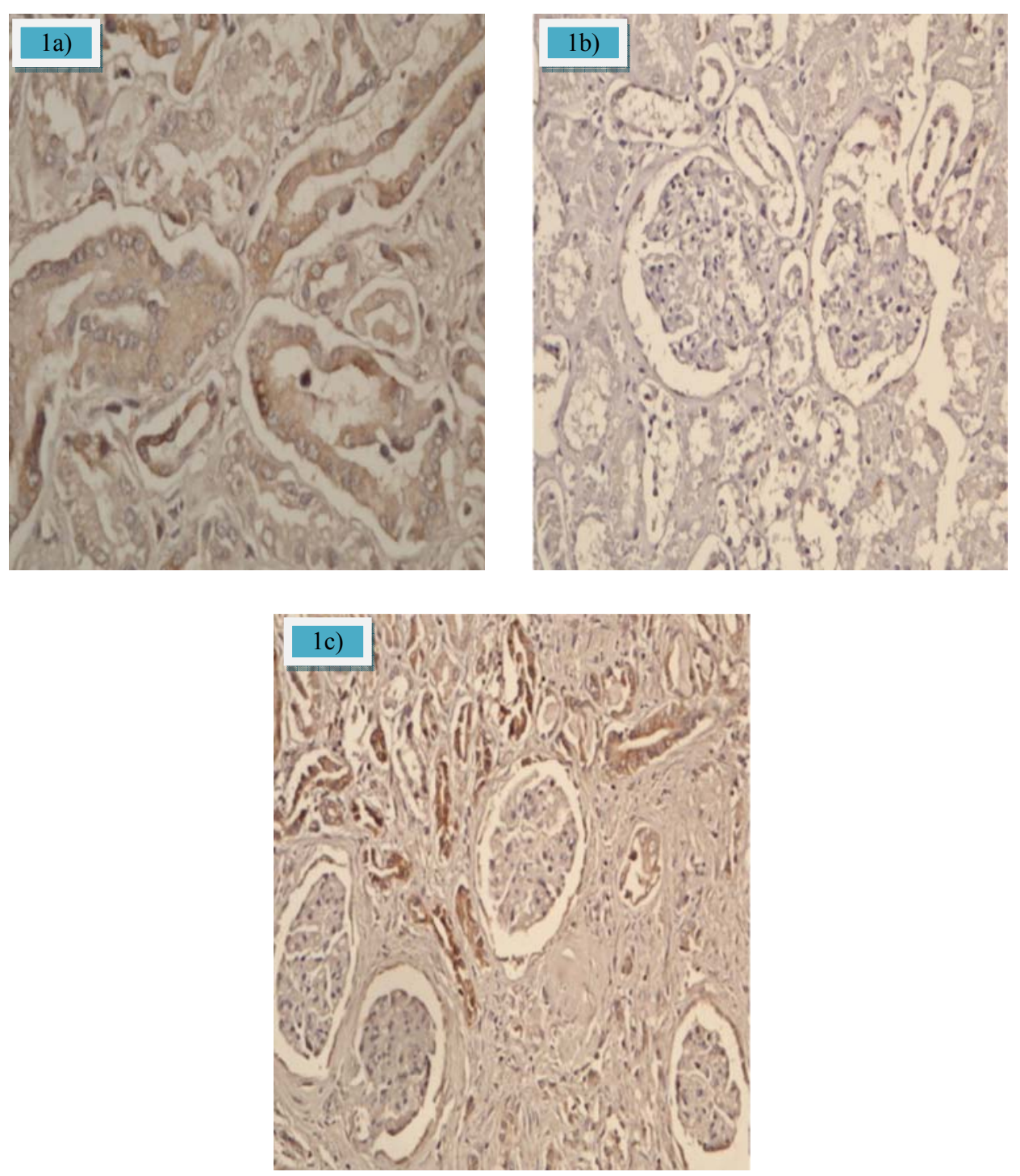

Figure 1. Bcl-2 expression: 1a). Control (x400); 1b). Diabetes (x200); 1c). Diabetic nephropathy (x200). 

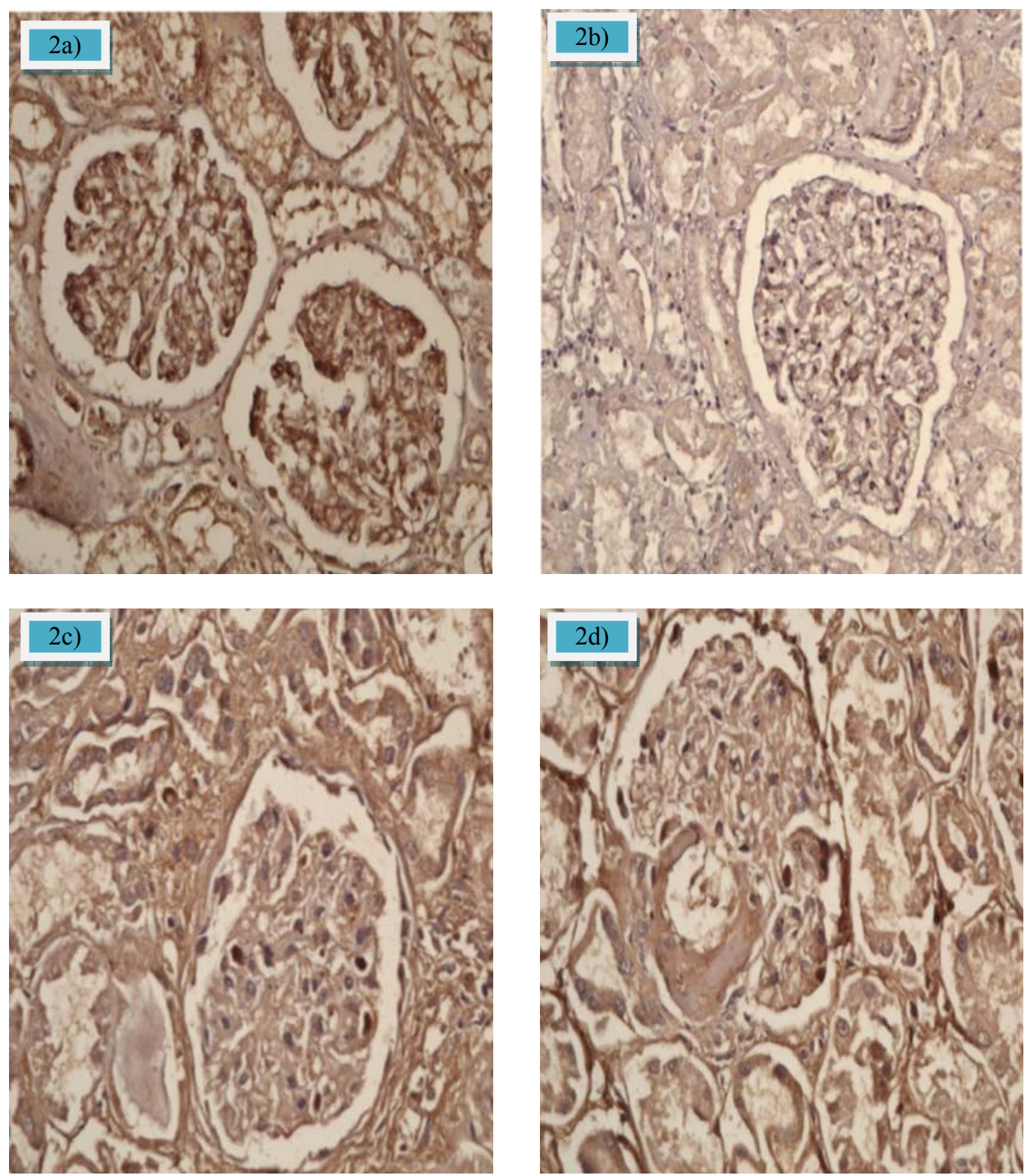

Figure 2. CD95 expression: 2a). Control (x200); 2b). Prediabetes (x200); 2c). Diabetes (x400); 2d). Diabetic nephropathy (x400).
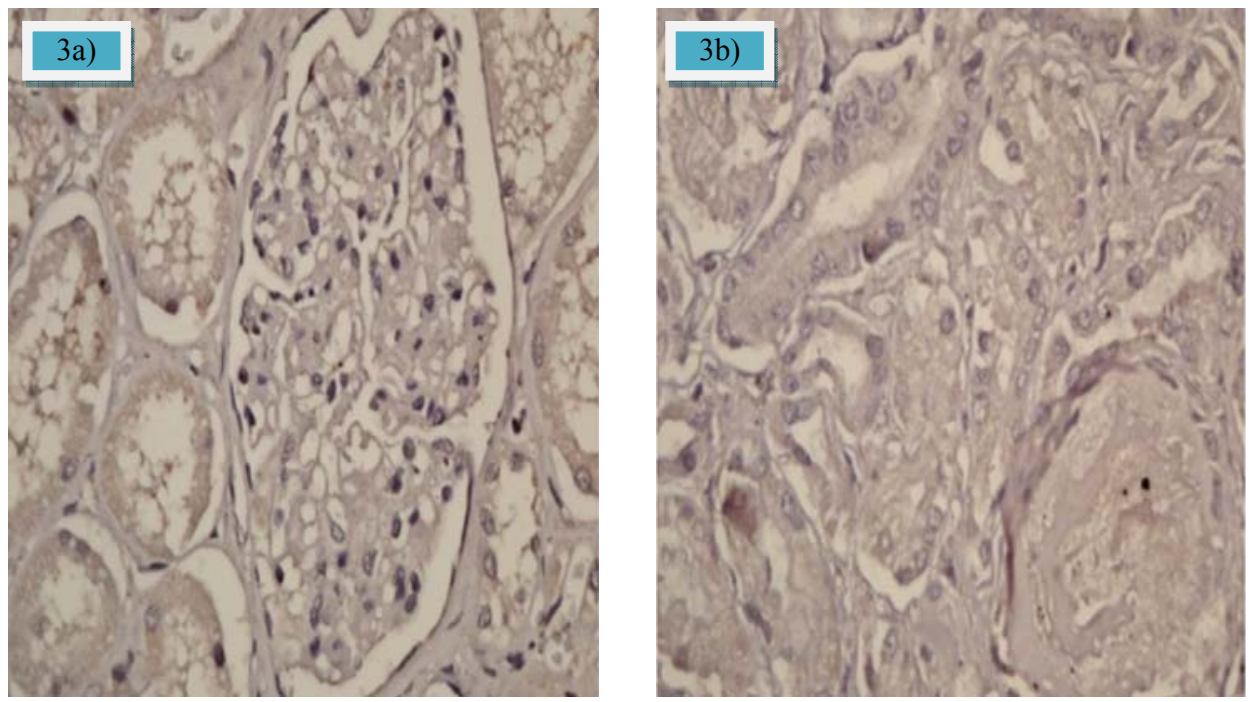

Figure 3. APAF-1 expression: 3a). Diabetes (x400); 3b). Diabetic Nephropathy (x400). 

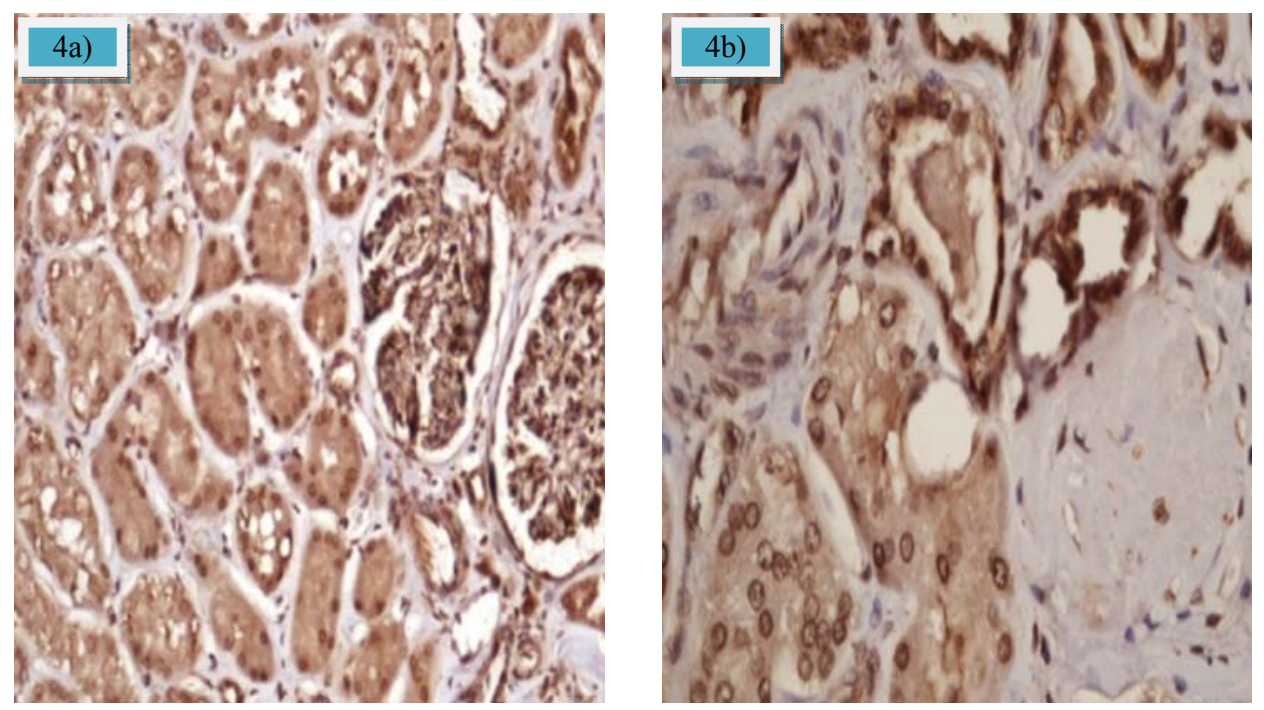

Figure 4. Caspase-9 expression: 4a). Diabetes (x200); 4b). Diabetic Nephropathy (x400).

Table 1

Bcl-2 expression in renal tissue study samples

\begin{tabular}{|l|c|c|}
\hline \multicolumn{3}{|c|}{ Bcl-2 } \\
\hline & $\mathbf{. + ( \% ) . ~}$ & $\mathbf{. ( \% ) . ~}$ \\
\hline Control group & $3(60 \%)$ & $2(40.00 \%)$ \\
\hline Prediabetes & $5(35.71 \%)$ & $9(64.28 \%)$ \\
\hline Diabetes (without renal impairment) & $2(16.66 \%)$ & $10(83.33 \%)$ \\
\hline Diabetic nephropathy & $3(17.64 \%)$ & $14(82.35 \%)$ \\
\hline Total & 13 & 35 \\
\hline
\end{tabular}

Table 2

APAF-1 expression in renal tissue study samples

\begin{tabular}{|l|c|c|}
\hline \multicolumn{3}{|c|}{ APAF-1 } \\
\hline & $\mathbf{. + ( \% ) .}$ &. $\mathbf{- ( \% ) .}$ \\
\hline Control group & $0(00.00 \%)$ & $5(100.00 \%)$ \\
\hline Prediabetes & $2(14.28 \%)$ & $12(85.71 \%)$ \\
\hline Diabetes (without renal impairment) & $0(00.00 \%)$ & $12(100.00 \%)$ \\
\hline Diabetic nephropathy & $6(35.29 \%)$ & $11(64.70 \%)$ \\
\hline Total & 8 & 40 \\
\hline
\end{tabular}

Table 3

CD-95 expression in renal tissue study samples

\begin{tabular}{|l|c|c|}
\hline \multicolumn{3}{|c|}{ CD-95 } \\
\hline & $\mathbf{. + ( \% ) .}$ & $\mathbf{. ( \% ) .}$ \\
\hline Control group & $5(100 \%)$ & $0(00.00 \%)$ \\
\hline Prediabetes & $6(42.85 \%)$ & $8(57,15 \%)$ \\
\hline Diabetes (without renal impairment) & $3(25.00 \%)$ & $9(75.00 \%)$ \\
\hline Diabetic nephropathy & $7(41.17 \%)$ & $10(58.83 \%)$ \\
\hline Total & 21 & 27 \\
\hline
\end{tabular}

Table 4

Caspase-9 expression in renal tissue study samples

\begin{tabular}{|l|c|c|}
\hline \multicolumn{3}{|c|}{ Caspase-9 } \\
\hline & $\mathbf{. + ( \% ) .}$ & $\mathbf{. ( \% )}$ \\
\hline Control group & $5(100.00 \%)$ & $0(00.00 \%)$ \\
\hline Prediabetes & $7(50.00 \%)$ & $7(50.00 \%)$ \\
\hline Diabetes (without renal impairment) & $11(91.66 \%)$ & $1(8.33 \%)$ \\
\hline Diabetic nephropathy & $17(100.00 \%)$ & $0(00.00 \%)$ \\
\hline Total & 40 & 8 \\
\hline
\end{tabular}




\section{DISCUSSION}

\section{CELL DEATH}

The three major pathways of cell death described by the medical literature (apoptosis, necrosis and autophagy) [7] involve both preservation of tissue homeostasis and adaptation to an environment less proper to life. Apoptosis maintains tissue homeostasis [8], removing unwanted or useless cells during development. Autophagy means death of cells deprived of growth factors, which survive by digesting their own organelles or macromolecules [9]. Necrosis is an accidental form of cell death initiated or modulated under programmed control mechanisms $[7,8,11,12]$.

In a damaged or stressed cell, death mechanisms might be triggered by activating death cell receptors (members of the TNF receptor family) as a result of an increased synthesis of specific ligands or of mitochondria impairment increasing synthesis of death cell receptors [7, 8, 13]. Mitochondria impairment (through an increased permeability of the inner membrane) with the subsequent cytochrome $\mathrm{C}$ cytosolic release and APAF-1 activation, are the first steps in the intrinsic apoptosis signaling pathway. Cytochrome $\mathrm{C}$ and APAF-1 in the presence of dATP form a multimolecular complex named apoptosome [14] which binds and activates procaspase-9. Further, initiator caspase- 9 has the ability to cleave the executioner caspases 3, 6 and 7 causing activation of the apoptotic process and cell death [8], though the role of caspases in apoptosis induced in pathologic states differs from natural cell death models [15].

\section{DIABETES AND IMBALANCE IN CELLULAR SIGNALING}

Due to an inappropriate activation of some intracellular signaling pathways, a loss of balance between cell death and cell proliferation occurs in diabetes, the signaling pathways of MAPk (mitogenactivated protein kinase) $[5,16]$ and protein kinase $\mathrm{B} / \mathrm{Akt}[8,16]$ to be incriminated.

Activation of MAP kinases and MAPk pathway signaling $[5,17]$ to the detriment of signaling on the AKT pathway will impede growth of cell cycle in the first stages due to persistent hyperglycemia. Up-regulation of MAPk pathway was also explained by cellular stress and inflammation occurrence, nitric oxide synthase activation and consequent pro or anti-apoptotic actions of NO synthesized, and by the accumulation of pro-fibrotic factors [18]. The occurrence of this imbalance in the cellular signaling pathways can mediate apoptosis, both through specific membrane death receptor activation (extrinsic pathway) as well as by mitochondrial damage (intrinsic pathway), with cross talk between them [7].

In diabetic nephropathy, an imbalance was also observed in terms of interaction between pro and anti-apoptotic members of Bcl-2 family, with down-regulation of anti-apoptotic Bcl-2 protein [6]. There are studies $[19,20,21]$ which indicated that some Bcl-2 family members can inhibit apoptotic death by controlling caspases activation and mitochondrial membrane permeability (preventing the release of cytochrome $\mathrm{C}$ [7] into the cytosol). Accumulation of $\mathrm{Bcl}-2$ proteins can occur through MAP kinases signaling and represents a stimulus for intrinsic apoptotic events, with APAF-1 [21] and initiator caspase- 9 activation, followed by the activation of the -3 and -7 executioner caspases, with cell death and further typical kidney lesions [21]: glomerular membrane expansion, tubular cell hypertrophy, accumulation of extracellular matrix, progressive glomerulosclerosis and tubulointerstitial fibrosis [16].

\section{ARGUMENTS FOR APOPTOTIC CELL DEATH}

Our study detected a variable expression of the antiapoptotic $\mathrm{Bcl}-2$ protein (positive in the capsular parietal cell and in the proximal and distal tubules). In control samples Bcl-2 positivity was observed also in the inflammatory cells. Bcl-2 was more frequently expressed in samples from control group compared with all other samples. Although there were tissue samples from diabetic nephropathy group in which Bcl-2 was frequently expressed, the entire study group showed an overall tendency towards loss of expression of $\mathrm{Bcl}-2$ with progression of renal damage in diabetes. Regarding the Bcl-2 variability we have also considered the involving of autolysis in some of the examined samples.

The strong positive expression of CD-95 in control samples (at both glomerular and tubular level) compared with CD-95 positivity in only a quarter of cases of diabetes and less than half of cases with diabetic nephropathy require further study. This finding may suggest that cells are prepared for programmed cell death (extrinsic pathway of apoptosis), as well as for non-apoptotic events, knowing that CD-95 can be considered as a trademark of the autophagy process [22]. 
Concerning APAF-1 immunostaining, we identified APAF-1 positivity in proximal tubular cells in control samples and it was observed an increased number of APAF-1 positive cases (both glomerular and tubular cells) in diabetic nephropathy samples compared to all other groups (control, prediabetes and diabetes without renal impairment). APAF-1 positivity was statistically significant in diabetic nephropathy group comparing with diabetes without renal impairment group thus suggesting a cellular signaling on intrinsic pathway of apoptosis.

Consistent with APAF-1 expression as a hallmark of the apoptotic intrinsic pathway, Caspase-9 staining revealed more frequent tubular and glomerular cell positivity with the kidney damage progression. Caspase- 9 positivity was observed at cytoplasm and nuclear level; the nuclear positivity of caspase- 9 may be explained by its ability to increase the nuclear pore permeability, thus allowing to some molecules (such as caspase-3) to cross the nuclear membrane and participate in nuclear structures dismantling [23, 24], eventually leading to apoptotic cell death. Even if Caspase-9 expression was present in almost all cases $(100 \%$ of control group, $100 \%$ of diabetic nephropathy and $91.66 \%$ of diabetic group) the lowest proportion of positivity being recorded among prediabetic samples $(50 \%)$, there is a high statistical significance in terms of Caspase-9 positivity in diabetic nephropathy samples compared to prediabetic group $(\mathrm{p}=0.001)$.

In the current study, APAF-1 $(+) /$ caspase$9(++) / \mathrm{Bcl}-2(+/-)$ glomerular and tubular cell phenoltype indicates an involvement of an intrinsic mechanism of apoptotic cell death in diabetic nephropathy, thus completing a previous study [25] demonstrating a renal cellular phenotype (TRADD $(+) /$ caspase- $8(+) /$ caspase-3(-)) suggestive for an extrinsic mechanism of apoptotic cell death in diabetic nephropathy.

\section{CONCLUSIONS}

In addition to controlling risk factors of diabetes or its complications once diabetes was installed, particular attention should be paid to long-term metabolic control in order to decrease inflammation, cellular stress, accumulation of profibrotic factors and the emergence of irreversible renal damages. Keeping a balance between prolixferation and cell death represents structural and functional premises of normality both at micro and macroscopic level.

Our present data shows that Bcl-2, CD95, APAF-1 and caspase-9 represent reliable markers of cell death in human renal tissue, and confirm the loss of balance between cell death and cell prolixferation in favor of cell death in diabetic renal disease. Our study identified proofs of apoptotic cell death mechanisms in the renal structures from diabetic human kidney samples, considering apoptosis as a pathogenic and initiator mechanism of renal remodeling. Furthermore, cell death mechanisms depend on the cellular context and the deathinducing stimulus; the involvement of specific death molecules may depend on specific tissular regions (a possible explanation for the variability in Bcl-2 expression).

All the above represent arguments for targeting cellular death processes as therapeutic directions to diminish the progression of renal ultrastructural lesions. This intervention might be achieved on different levels of cellular signaling pathways by acting upon the key elements of the pathological apoptotic process - death receptors, caspases, Apaf-1/cytochrome C complex.

\begin{abstract}
Acknowledgments. This paper is supported by the Sectoral Operational Programme Human Resources Development (SOP HRD), financed from the European Social Fund and by the Romanian Government under contract number POSDRU/ 159/1.5/S/132395 (author no.1)

This paper was partially presented within the "National Congress of the Romanian Pathophysiology Society with International Participation", Iasi, Romania, May 7-10, 2015 and the " $14^{\text {th }}$ European Congress of Internal Medicine", Moscow, Russia, October 14-16, 2015.
\end{abstract}

Declaration of interest: The authors declare that there are not conflicts of interest.

Authors' contribution: All authors have contributed equally to this study.

Introducere. Diabetul zaharat determină modificări ultrastructurale declanşate de mecanisme celulare parțial clarificate. Intrucât moartea celulară este un mecanism important în apariția şi progresia nefropatiei diabetice, am studiat modificările câtorva markeri ai semnalizării celulare pe calea apoptotică în țesutul renal provenit de la pacienți cu diabet sau tulburare de glicoreglare. 
Metodă. Am analizat 48 de probe tisulare renale umane împărțite în două loturi de studiu - lotul de cercetare (43 de probe provenite de la pacienți diabetici sau pacienți cu tulburare de glicoreglare) şi lotul martor (5 probe tisulare renale provenite de la pacienți fără diabet). Prin imunohistochimie s-a evidențiat expresia Bcl-2, APAF-1, CD-95, Caspaza-9 în structurile corticale renale. A fost efectuată analiza statistică (nivelul de semnificație statistică $p<0.05$ ).

Rezultate. Am găsit o expresie variabilă a proteinei antiapoptotice $\mathrm{Bcl}-2 \mathrm{cu}$ o scădere a expresiei Bcl-2 în diabet. Probele martor au evidențiat imunomarcare intens pozitivă pentru CD-95. In diabet şi nefropatia diabetică $s$-a observat imunomarcare pozitivă pentru APAF-1 la nivelul celulelor tubulare. Pozitivitatea nucleară şi citoplasmatică pentru Caspza-9 a fost mai frecvent înregistrată odată cu progresia leziunilor renale. Pozitivitatea APAF-1 şi Caspaza-9 sunt argumente pentru un mecanism apoptotic intrinsec al morții celulare în nefropatia diabetică.

Concluzii. Mecanismele morții celulare apoptotice identificate in probele tisulare renale demonstrează că Bcl-2, CD-95, APAF-1 şi Caspaza-9 reprezintă adevărați markeri ai morții celulare în țesutul renal uman. Rezultatele noastre susțin ipoteza că apoptoza este un mecanism patogenic şi declanşator al remodelării renale în boala renală diabetică.

Correspondence to: Mirela Cioplea,

"Colentina" Clinical Hospital, Department of Pathology,

19-21 Ştefan cel Mare str., 020125, Bucharest, Romania

Tel. +40213173245 , Fax +40213165512

E-mail: petremireladaniela@yahoo.com

\section{REFERENCES}

1. IFKF. World Kidney Day -Kidney Health for All. 2015 [cited 17.08.2015]; Available from:http://www.worldkidneyday.org/ topics/diabetes/http://www.niddk.nih.gov/health-information/health-topics/kidney-disease/kidney-disease-of-diabetes/Documents/kdd_ 508.pdf

2. WHO. Diabetes Fact sheet $N^{\circ} 312.2015$ January 2015 [cited 28.02.2015]; Available from: http://www.who.int/mediacentre/ factsheets/fs312/en/

3. WHO. Noncommunicable diseases - Fact sheet 2015 January 2015 [cited 31.07.2015]; Available from: http://www.who.int/ mediacentre/factsheets/fs355/en/

4. BATUMAN V, SOMAN A, SCHMIDT R, SOMAN S. Diabetic Nephropathy. [cited 07.05.2015] Available from: http:// emedicine.medscape.com/article/238946-overview.

5. ADA, Standards of medical care in diabetes-2015 abridged for primary care providers. Clin Diabetes. 2015; 33(2): 97-111.

6. HOTCHKISS RS, STRASSER A, McDUNN JE, SWANSON PE. Cell death. N Engl J Med. 2009; 361(16): 1570-83.

7. ELMORE S. Apoptosis: a review of programmed cell death. Toxicol Pathol. 2007; 35(4): 495-516.

8. DING Y, CHOI ME. Autophagy in diabetic nephropathy. J Endocrinol. 2015; 224(1): R15-30.

9. SANCHEZ-NINO MD, BENITO-MARTIN A, ORTIZ A. New paradigms in cell death in human diabetic nephropathy. Kidney Int. 2010; 78(8): 737-44.

10. SINKOVICS JG. Programmed cell death (apoptosis): its virological and immunological connections (a review). Acta Microbiol Hung. 1991; 38(3-4): 321-34.

11. CABON L, MARTINEZ-TORRES AC, SUSIN SA. Programmed cell death comes in many flavors. Med Sci (Paris). 2013; 29(12): 1117-24.

12. ACEHAN D, JIANG X, MORGAN DG, HEUSER JE, WANG X, AKEY CW. Three-dimensional structure of the apoptosome: implications for assembly, procaspase-9 binding, and activation. Mol Cell. 2002; 9(2): 423-32.

13. OO TF, SIMAN R, BURKE RE. Distinct nuclear and cytoplasmic localization of caspase cleavage products in two models of induced apoptotic death in dopamine neurons of the substantia nigra. Exp Neurol. 2002; 175(1): 1-9.

14. ALPERN R, CAPLAN M, MOE O. Seldin and Giebisch's the kidney; Physiology \& pathophysiology. Academic Press; 2012. p. 2605-23.

15. RANE MJ, SONG Y, JIN S, BARATI MT, WU R, KAUSAR H, et al. Interplay between Akt and p38 MAPK pathways in the regulation of renal tubular cell apoptosis associated with diabetic nephropathy. Am J Physiol Renal Physiol. 2010; 298(1): F49-61.

16. WOLF G, SCHROEDER R, ZIYADEH FN, THAISS F, ZAHNER G, STAHL RA. High glucose stimulates expression of p27Kip1 in cultured mouse mesangial cells: relationship to hypertrophy. Am J Physiol. 1997; 273(3 Pt 2): F348-56.

17. DAVIS RJ. The mitogen-activated protein kinase signal transduction pathway. J Biol Chem. 1993; 268(20): 14553-6.

18. MARTIN AG, FEARNHEAD HO. Apocytochrome c blocks caspase-9 activation and Bax-induced apoptosis. J Biol Chem. 2002; 277(52): 50834-41. 
19. YANG E, ZHA J, JOCKEL J, BOISE LH, THOMPSON CB, KORSMEYER SJ. Bad, a heterodimeric partner for Bcl-XL and Bcl-2, displaces Bax and promotes cell death. Cell. 1995; 80(2): 285-91.

20. NEWMEYER DD, BOSSY-WETZEL E, KLUCK RM, WOLF BB, BEERE HM, GREEN DR. Bcl-xL does not inhibit the function of Apaf-1. Cell Death Differ. 2000; 7(4): 402-7.

21. ALMOND JB, COHEN GM. The proteasome: a novel target for cancer chemotherapy. Leukemia. 2002; 16(4): 433-43.

22. TOWNS R, PIETROPAOLO M, WILEY JW. Stimulation of autophagy by autoantibody-mediated activation of death receptor cascades. Autophagy. 2008; 4(5): 715-6.

23. FALEIRO L, LAZEBNIK Y. Caspases disrupt the nuclear-cytoplasmic barrier. J Cell Biol. 2000; 151(5): 951-9.

24. KRAMER A, LIASHKOVICH I, OBERLEITHNER H, SHAHIN V. Caspase-9-dependent decrease of nuclear pore channel hydrophobicity is accompanied by nuclear envelope leakiness. Nanomedicine. 2010; 6(5): 605-11.

25. BĂLĂŞESCU E, DUȚĂ I, RUSU MC. Human diabetic nephropathy: TRADD-positive and bcl2-negative podocytes. Therapeutics, Pharmacology and Clinical Toxicology. 2013;17(3):115-8.

Received October 1, 2015 